\title{
Molecular and serological detection of Ehrlichia spp. in cats on São Luís Island, Maranhão, Brazil
}

\author{
Detecção molecular e sorológica de Ehrlichia spp. em gatos da ilha de São Luís, Maranhão, Brasil \\ Maria do Socorro Costa de Oliveira Braga ${ }^{1}$; Marcos Rogério André2 ${ }^{2}$ Carla Roberta Freschi ${ }^{2}$; \\ Márcia Cristina Alves Teixeira²; Rosangela Zacarias Machado² \\ ${ }^{1}$ Universidade Estadual do Maranháo - UEMA \\ ${ }^{2}$ Universidade Estadual Paulista - UNESP
}

Received April 26, 2011

Accepted July 12, 2011

\begin{abstract}
Ehrlichiosis is a tick-borne disease that affects both humans and animals. The few existing reports on ehrlichiosis in Brazilian cats have been based on observation of morulae in leukocytes and, more recently, on molecular detection of Ehrlichia sp. In this study, we assessed occurrences of Ehrlichia sp. in the blood of 200 domestic cats in São Luís, Maranhão. Of the 200 animals tested, 11 (5.5\%) were seropositive for Ehrlichia sp. and two (1\%) were positive for Ehrlichia sp. in PCR. We also performed DNA sequence alignment to establish the identity of the parasite species infecting these animals, using the gene $16 \mathrm{~S}$ rRNA. One cat presented infection with Ehrlichia sp. with $98 \%$ identity with E. canis, and another cat infected with Ehrlichia sp. showed 97\% identity with E. chaffeensis. This is the first study on molecular detection of Ehrlichia sp. among domestic cats in São Luís, Maranhão.
\end{abstract}

Keywords: Cats, Ehrlichia sp., serology, PCR, Brazil.

\section{Resumo}

Erliquiose é uma enfermidade transmitida por carrapatos que afeta seres humanos e animais. Os poucos relatos de erliquiose em gatos, no Brasil, são baseados na observação de mórulas em leucócitos e, mais recentemente, na detecção molecular de Ehrlichia sp. Neste estudo, foi avaliada a ocorrência de Ehrlichia sp. no sangue de 200 gatos de São Luís, Maranhão. Dos 200 animais testados, 11 (5,5\%) foram soropositivos para Ehrlichia sp. e dois (1\%) foram positivos na PCR para Ehrlichia spp. O alinhamento de sequências de DNA baseado no gene 16S rRNA foi conduzido para estabelecer a identidade da espécie de parasito que infectou estes animais. Um gato apresentou infecção por uma espécie de Ehrlichia sp. com 98\% de identidade com E. canis; e outro mostrou-se infectado por Ehrlichia sp. com 97\% de identidade com E. chaffeensis. Este estudo traz a primeira detecção molecular de Ehrlichia sp. em gatos de São Luís, Maranhão.

Palavras-chave: Gatos, Ehrlichia sp., sorologia, PCR, Brasil.

\section{Introduction}

Ehrlichiosis is an emerging tick-borne disease that affects both humans and animals (WALKER; DUMLER, 1996). The clinical signs and abnormal laboratory findings relating to ehrlichiosis are similar in felids and canids (ALMOSNY et al., 1998). Suggestive morulae from agents in the family Anaplasmataceae have been detected among cats in France (BEAUFILS et al., 1999), Sweden (BJÖERSDORFF et al., 1999) and Italy (TARELLO, 2005). Some serological studies have demonstrated that antibodies

\footnotetext{
*Corresponding author: Rosangela Zacarias Machado

Laboratório de Imunoparasitologia, Departamento de Patologia Veterinária,

Faculdade de Ciências Agrárias e Veterinárias Júlio de Mesquita Filho,

Universidade Estadual Paulista -UNESP, Campus de Jaboticabal,

Via de Acesso Prof. Paulo Donato Castellane, sn, Zona Rural,

CEP 14884-900, Jaboticabal, SP, Brazil

e-mail: zacarias@fcav.unesp.br
}

against agents in the family Anaplasmataceae are present in cat serum (MATTHEWMAN et al., 1996; AGUIRRE et al., 2004; ORTUÑO et al., 2005; SOLANO-GALLEGO et al., 2006). The presence of DNA from Ehrlichia sp. has been detected among domestic cats in the United States (BREITSCHWERDT et al., 2002), Taiwan (YIN-CHIACHUN et al., 2003), Spain (TABAR et al., 2007) and Brazil (OLIVEIRA et al., 2009). DNA from Anaplasma phagocytophilum has been detected in the blood of domestic cats in Sweden (BJÖERSDORFF et al., 1999) and the United States (LAPPIN et al., 2004).

Otherwise, very little is known about the presence of ehrlichiosisbased pathogens in Brazilian cats. In Brazil, the first occurrence of feline ehrlichiosis was reported in 1998, in which morulae of mono and polymorphonuclear leukocytes were observed in 
a cat, with clinical and laboratory findings similar to those of canine ehrlichiosis (ALMOSNY et al., 1998). Recently, DNA from $E$. canis was detected in blood samples from cats in the state of Minas Gerais (OLIVEIRA et al., 2009). A high titer of antibodies against $E$. canis was detected in a free-ranging puma in Brazil (FILONI et al., 2006). Moreover, DNA from Ehrlichia spp. and antibodies against E. canis have been detected in blood samples from wild felids in the state of São Paulo and in Brasília (ANDRÉ et al., 2010). The present work aimed to detect the presence of Ehrlichia spp. in blood samples from cats in São Luís, Maranhão, Brazil, using molecular and serological techniques.

\section{Material and Methods}

Between October 2008 and January 2009, EDTA whole blood and serum samples were collected from 200 domestic cats in São Luís, Maranhão, Brazil. The blood and serum samples were stored at $-20^{\circ} \mathrm{C}$.

The presence of anti-Ehrlichia canis antibodies in the serum samples from each animal was detected by means of the indirect immunofluorescent assay (IFA). Antigen slides were removed from storage and allowed to thaw at room temperature for 30 minutes. Ten microliters of twofold dilutions of serum at 1:64 (cut-off) were placed in wells on antigen slides. Antigens of Ehrlichia canis were obtained by culturing DH82 cells infected with E. canis (Jaboticabal strain) at the Immunoparasitology Laboratory, UNESP (AGUIAR et al., 2007b). Known positive canine serum (titer 1:2,560) was obtained from a symptomatic dog with ehrlichiosis at Governador Laudo Natel Veterinary Hospital, UNESP, Jaboticabal, São Paulo. When highly positive serum was obtained from a feline (titer of 2,560), it was used as a positive control. Test serum samples that had been analyzed using a canine positive control were reprocessed again using a feline positive control. The negative control serum sample was obtained from a cat that had not been exposed to this agent, according to negative PCR and IFA results.

The slides were incubated at $37^{\circ} \mathrm{C}$ in a moist chamber for 30 minutes, washed three times in PBS ( $\mathrm{pH}$ 7.2) for 5 minutes, and air dried at room temperature. Anti-cat conjugate (dilution of 1:100) for feline samples and anti-dog conjugate for controls (dilution of 1:80) were diluted in accordance with the manufacturer's instructions and then added to each well. These slides were incubated again, washed, dried and overlain with buffered glycerin $(\mathrm{pH}$ 8.7), covered with glass coverslips and examined using a fluorescence microscope (NAKAGHI et al., 2008).

DNA was extracted from $200 \mu \mathrm{L}$ of EDTA whole blood from felines, using the QIAamp DNA blood mini-kit (QIAGEN, Valencia, California, USA), in accordance with the manufacturer's instructions. Each sample of extracted DNA was used as a template in a nested PCR with genus-specific primers (478 bp) and speciesspecific primers for Ehrlichia canis (358 bp) (MURPHY et al., 1998) and E. chaffeensis (410 bp) (KOCAN et al., 2000). A positive DNA control for Ehrlichia canis was obtained from a dog that had been experimentally infected with the Jaboticabal E. canis strain. The positive control for Ehrlichia chaffeensis was kindly supplied by J. Stephen Dumler, Department of Pathology,
Johns Hopkins School of Medicine, Baltimore, Maryland, USA. A negative domestic cat blood sample was used as the negative control. The PCR and nested PCR amplifications were performed in a Gradient Cycler (Perkin-Elmer ${ }^{\mathrm{TM}}$ model PT-200).

PCR amplicons were ligated into pGEM-T Easy Vector followed by transformation of DH10B Escherichia coli using the pGEM cloning kit (Promega, Madison, Wisconsin, USA), in accordance with the manufacturer's instructions. The resulting clones underwent blue/white colony screening. Plasmid DNA from the positive clones was isolated by means of the alkaline lysis method (SAMBROOK; RUSSEL, 2001) and was subjected to sequence determination (ABI Prism 310 Genetic Analyzer, Applied Biosystems/Perkin Elmer, Foster City, California, USA). Consensus sequences were obtained using the CAP3 software (http://mobyle.pasteur.fr/cgi-bin/MobylePortal/portal.py) for subsequent phylogenetic analysis and the BLAST tool was used to ascertain similarities with GenBank sequences. The CLUSTAL W (THOMPSON et al., 1994) and MEGA (KUMAR et al., 2004) software was used for alignment and phylogenetic analysis, respectively. The distance-based neighbor-joining method was used to build the phylogenetic tree (SAITOU; NEI, 1987) using the Kimura-2-parameter model. The bootstrap test with 1000 replications was used to estimate the confidence of branching patterns on the neighbor-joining tree (FELSENSTEIN, 1985).

\section{Results and Discussion}

Eleven (5.5\%) of the 200 cats tested were seropositive for E. canis antigens, according to IFA. The antibody titers ranged from 64 (cut-off) to 512 for E. canis. Three animals showed antibody titers of 64 and seven animals were seroreactive at a dilution of 1:160. Only one animal showed antibody titers of 512 .

Two (1\%) of the 200 samples were positive for Ehrlichia sp. PCR based on $16 \mathrm{~S}$ rRNA. One sample (cat\#45) was positive for E. canis $\mathrm{nPCR}$ and another one (cat\#211) for E. chaffeensis $\mathrm{nPCR}$. Both of the PCR-positive animals were negative in the serological test. DNA sequencing using the 16S rRNA gene showed that the Ehrlichia sp. DNA obtained from cat\#45 (GenBank access number JN123433) was closely related (98.0\% identity) to E. canis from dogs in Tunisia (EU781695), Taiwan (EU143637) and Italy (EU439944). The Ehrlichia sp. DNA obtained from cat\#211 (GenBank access number JN123434) was closely related (97.0\% identity) to E. chaffeensis isolated in Arkansas (AF416764), Ehrlichia sp. from Boophilus microplus in Tibet (AF414399) and Ehrlichia sp. from deer in Japan (AB454074). While the Ehrlichia sp. isolate from cat $\# 45$ clustered together with $E$. canis isolates, the Ehrlichia sp. from cat\#211 clustered together with E. chaffeensis isolates (Figure 1).

To our knowledge, the present study is the first to show the presence of DNA from Ehrlichia spp. among cats in the state of Maranhão, Brazil. Ehrlichia DNA has been detected among cats in the United States (BREITSCHWERDT et al., 2002), Spain (TABAR et al., 2007) and Brazil (OLIVEIRA et al., 2009). Ehrlichia spp. DNA and antibodies to this agent have been detected in blood samples from wild felids that were kept in captivity in the state of São Paulo and the Brazilian Federal District (ANDRÉ et al., 


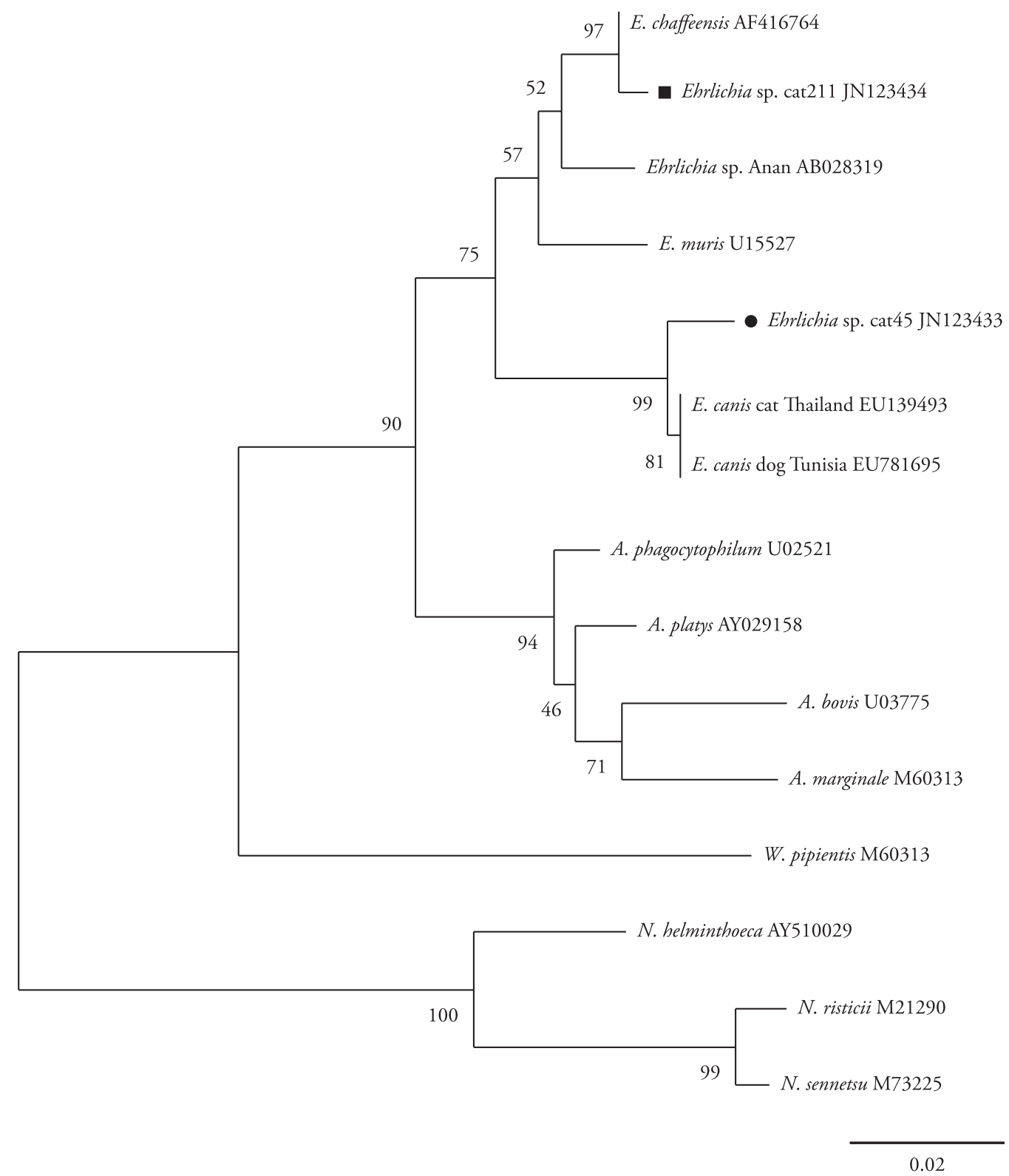

Figure 1. Phylogenetic position of Ehrlichia sp. isolates from Brazilian domestic cats on Sáo Luís island, based on 16S rRNA sequences (300 bp). The tree was constructed using the neighbor-joining method and the numbers on the tree indicate bootstrap values for the branch points. Accession numbers and place of origin of the isolates are shown beside the sequence names.

2010). Furthermore, DNA from Anaplasma phagocytophilum has been detected among cats in Sweden (BJÖERSDORFF et al., 1999) and the United States (LAPPIN et al., 2004).

The low percentage of positive animals in the present study and other studies can possibly be explained by considering the fact that cats are more resistant to Ehrlichia infection than dogs are, and they interact differently with the tick vector. Most cats rapidly remove ticks when they become infested, and thus the minimum tick attachment time of 24-48 hours that is thought likely to be required for transmission of most tick-transmitted infections may not be achieved (KIDD; BREITSCHWERDT, 2003). It is also possible that cats have lower copy numbers of Ehrlichia DNA than shown by dogs, thereby resulting in false negative results (EBERHARDT et al., 2006). Moreover, these results show that Ehrlichia infections in cats are uncommon.

The percentage of seropositive animals in the present study was lower than that found in other studies on domestic cats (MATTHEWMAN et al., 1996; AGUIRRE et al., 2004; ORTUÑO et al., 2005; SOLANO-GALLEGO et al., 2006). The observed low antibody titers may result from a low humoral immune response to Ehrlichia sp. among cats, or may result from cross-reactivity with other Anaplasmataceae species (ORTUÑO et al., 2005). The occurrence of positive PCR and negative serological results suggests that genes from other organisms that are closely related to $E$. canis may also have been amplified, but were distinct enough not to induce cross-reacting antibodies (EBERHARDT et al., 2006). 
Although it has been suggested that feline ehrlichiosis is transmitted by ticks, the transmission mechanism still remains imperfectly understood (SHAWN, 2001). In Brazil, E. canis is transmitted to dogs by the tick Rhipicephalus sanguineus (AGUIAR et al., 2007a). Although E. chaffeensis DNA has been detected in Brazilian marsh deer, there is no information about its transmission route (MACHADO et al., 2006). Although the samples for the present study were collected during the summer, ticks were found attached in only one of the sampled animals (Rhipicephalus sanguineus ticks in one cat that was negative to both PCR and serological tests; data not shown). It should be noted that exposure to vectors among felids is less frequent than among dogs. Alternatively, felids may remove the vectors before hemoparasite transmission occurs (LAPPIN et al., 2006). At present, the exposure route to $E$. canis among the cats studied here is unknown.

The role of cats in the epidemiology of ehrlichiosis is unknown. It has been suggested that felids are more resistant to infection than are dogs (LAPPIN et al., 2006). The presence of Ehrlichia sp. closely related to $E$. chaffeensis in one cat in the present study, along with reports of antibodies to $E$. chaffeensis both in humans (CALIC et al., 2004; DA COSTA et al., 2005, 2006) and in dogs (GALVÁO et al., 2002) in the state of Minas Gerais, Brazil, and the molecular detection of this agent in Brazilian marsh deer (Blastocerus dichotomus) (MACHADO et al., 2006), shows that there is a need for more studies on the zoonotic potential represented by domestic and wild animals in Brazil, taking into consideration the existence of human monocytic ehrlichiosis.

The present work shows that Brazilian cats have been exposed to Ehrlichia sp. infection. To determine whether this finding represents a real threat to the health of these animals, further studies are needed. To our knowledge, this is the first study on molecular detection of Ehrlichia sp. among cats in the state of Maranhão.

\section{Acknowledgements}

The authors would like to thank Conselho Nacional de Desenvolvimento Científico e Tecnólogico (CNPq) and Fundação de Amparo à Pesquisa do Estado de São Paulo (Fapesp) for the financial support, and Dr. John Stephen Dumler from Johns Hopkins University School of Medicine, Baltimore, MD, USA, for providing the positive DNA control for Ehrlichia chaffeensis.

\section{References}

Aguiar DM, Cavalcante GT, Pinter A, Gennari SM, Camargo LM, Labruna MB. Prevalence of Ehrlichia canis (Rickettsiales: Anaplasmataceae) in dogs and Rhipicephalus sanguineus (Acari: Ixodidae) ticks from Brazil. J Med Entomol 2007a; 44(1): 126-132. http://dx.doi. org/10.1603/0022-2585(2007)44[126:POECRA]2.0.CO;2

Aguiar DM, Saito TB, Hagiwara MK, Machado RZ, Labruna MB. Serological diagnosis of canine monocytic ehrlichiosis with Brazilian antigen of Ehrlichia canis. Cienc Rural 2007b; 37(3): 796-802. http://dx.doi.org/10.1590/S0103-84782007000300030

Aguirre E, Tesouro MA, Amusategui I, Rodríguez-Franco F, Sainz A. Assessment of feline ehrlichiosis in central Spain using serology and a polymerase chain reaction technique. Ann NY Acad Sci 2004; 1026: 103-105. PMid:15604476. http://dx.doi.org/10.1196/ annals. 1307.013

Almosny, NRP, Almeida LE, Moreira NM, Massard CL. Erliquiose clínica em gato (Felis catus). Rev Bras Cienc Vet 1998; 5(2): 82-83.

André MR, Adania CH, Machado RZ, Allegretti SM, Felippe PA, Silva KF et al. Molecular and serologic detection of Ehrlichia spp. in endangered Brazilian wild captive felids. J Wildl Dis 2010; 46(3): 1017-1023. PMid:20688716.

Beaufils, JP, Martin-Granel J, Jumelle P, Barbault-Jumelle M. Ehrlichiosis in cats. A retrospective study of 21 cases. Prat Med Chir Anim Cie1999; 34(5): 587-596.

Bjöersdorff A, Svendenius L, Owens JH, Massung RF. Feline granulocytic ehrlichiosis - a report of a new clinical entity and characterisation of the infectious agent. J Small Anim Pract 1999; 40(1): 20-24. http://dx.doi. org/10.1111/j.1748-5827.1999.tb03249.x

Breitschwerdt EB, Abrams-Ogg AC, Lappin MR, Bienzle D, Hancock SI, Cowan SM et al. Molecular evidence supporting Ehrlichia canis-like infection in cats. J Vet Intern Med 2002; 16(6):642-649. PMid:12465759.

Calic SB, Galvão MA, Bacellar F, Rocha CM, Mafra CL, Leite RC et al. Human ehrlichioses in Brazil: first suspect cases. Braz J Infect Dis 2004; 8(3): 259-262. PMid:15476059. http://dx.doi.org/10.1590/ S1413-86702004000300011

Da Costa PS, Brigatte ME, Greco DB. Antibodies to Rickettsia rickettsii, Rickettsia typhi, Coxiella burnetii, Bartonella henselae, Bartonella quintana, and Ehrlichia chaffeensis among healthy population in Minas Gerais, Brazil. Mem Inst Oswaldo Cruz 2005; 100(8): 853-859. http://dx.doi. org/10.1590/S0074-02762005000800006

Da Costa PS, Valle LM, Brigatte ME, Greco DB. More about human monocytotropic ehrlichiosis in Brazil: serological evidence of nine new cases. Braz J Infect Dis 2006; 10(1): 7-10. PMid:16767308. http://dx.doi. org/10.1590/S1413-86702006000100002

De Oliveira LS, Mourão LC, Oliveira KA, Da Matta Agostini M, De Oliveira AC, De Almeida MR et al. Molecular detection of Ehrlichia canis in cats in Brazil. Clin Microbiol Infect 2009; 15(2): 53-54. PMid:19374643. http://dx.doi.org/10.1111/j.1469-0691.2008.02175.x

Eberhardt JM, Neal K, Shackelford T, Lappin MR. Prevalence of selected infectious disease agents in cats from Arizona. J Feline Med Surg 2006; 8(3): 164-168. http://dx.doi.org/10.1016/j.jfms.2005.12.002

Felsenstein J. Confidence limits on phylogenies: an approach using the bootstrap. Evolution 1985; 39(4): 783-791. http://dx.doi. org/10.2307/2408678

Filoni C, Catão-Dias JL, Bay G, Durigon EL, Jorge RS, Lutz H et al. First evidence of feline herpesvirus, calicivirus, parvovirus, and Ehrlichia exposure in Brazilian free-ranging felids. JWildl Dis 2006; 42(2):470-477. PMid:16870878.

Galvão MA, Lamounier JA, Bonomo E, Tropia MS, Rezende EG et al. Emerging and reemerging rickettsiosis in an endemic area of Minas Gerais State, Brazil. Cad Saude Publica 2002;18(6): 1593-1597. PMid:12488886.

Kidd L, Breitschwerdt EB. Transmission times and prevention of tick-borne diseases in dogs. Compend Cont Educ Pract Vet 2003; 25(10): 742-775.

Kocan AA, Levesque GC, Whitworth LC, Murphy GL, Ewing SA, Barker RW. Naturally occurring Ehrlichia chaffeensis infection in coyotes from Oklahoma. Emerg Infect Dis 2000; 6(5): 477-480. PMid:10998377. PMCid:2627953. http://dx.doi.org/10.3201/eid0605.000505 
Kumar S, Tamura K, Nei M. MEGA3: Integrated software for Molecular Evolutionary Genetics Analysis and sequence alignment. Brief Bioinform 2004; 5(2): 150-63. PMid:15260895. http://dx.doi. org/10.1093/bib/5.2.150

Lappin MR, Breitschwerdt EB, Jensen WA, Dunnigan B, Rha JY, Williams CR et al. Molecular and serologic evidence of Anaplasma phagocytophilum infection in cats in North America. J Am Vet Med Assoc 2004; 225(6): 893-896. PMid:15485049. http://dx.doi. org/10.2460/javma.2004.225.893

Lappin MR, Griffin B, Brunt J, Riley A, Burney D, Hawley J et al. Prevalence of Bartonella species, haemoplasma species, Ehrlichia species, Anaplasma phagocytophilum, and Neorickettsia risticii DNA in the blood of cats and their fleas in the United States. J Feline Med Surg 2006; 8(2):85-90. http://dx.doi.org/10.1016/j.jfms.2005.08.003

Machado RZ, Duarte JM, Dagnone AS, Szabó MP. Detection of Ehrlichia chaffeensis in Brazilian marsh deer (Blastocerus dichotomus). Vet Parasitol 2006; 139(1-3):262-6. PMid:16621285. http://dx.doi. org/10.1016/j.vetpar.2006.02.038

Matthewman LA, Kelly PJ, Wray K, Bryson NR, Rycroft AN, Raoult $\mathrm{D}$ et al. Antibodies in cat sera from southern Africa react with antigens of Ehrlichia canis. Vet Rec 1996; 138(15): 364-5. PMid:8737264. http://dx.doi.org/10.1136/vr.138.15.364

Murphy GL, Ewing SA, Whitworth LC, Fox JC, Kocan AA. A molecular and serologic survey of Ehrlichia canis, E. chaffeensis, and E. ewingii in dogs and ticks from Oklahoma. Vet Parasitol 1998; 79(4):325-39. http:// dx.doi.org/10.1016/S0304-4017(98)00179-4

Nakaghi ACH, Machado RZ, Tinucci-Costa M, André MR, Baldani CD. Canine ehrlichiosis: Clinical, hematological, serological and molecular aspects. Cienc Rural 2008; 38(3): 766-770. http://dx.doi.org/10.1590/ S0103-84782008000300027

Ortuño A, Gauss CB, García F, Gutierrez JF. Serological evidence of Ehrlichia spp. exposure in cats from northeastern Spain. J Vet Med B Infect Dis Vet Public Health 2005; 52(5): 246-248.
Saitou N, Nei M. The neighbor-joining method: a new method for reconstructing phylogenetic trees. Mol Biol Evol 1987; 4(4): 406-425. PMid:3447015.

Sambrook J, Russel DW. Molecular cloning: a laboratory manual. $3^{\text {nd }}$ ed. Cold Spring Harbor Laboratory Press, 2001, 999p.

Shaw SE, Birtles RJ, Day MJ. Arthropod-transmitted infectious diseases of cats. J Feline Med Surg 2001; 3(4): 193-209. http://dx.doi. org/10.1053/jfms.2001.0149

Solano-Gallego L, Hegarty B, Espada Y, Llull J, Breitschwerdt E. Serological and molecular evidence of exposure to arthropod-borne organisms in cats from northeastern Spain. Vet Microbiol 2006; 118(3-4): 274-247. PMid:16919405. http://dx.doi.org/10.1016/j.vetmic.2006.07.010

Tabar MD, Altet L, Francino O, Sánchez A, Ferrer L, Roura X. Vectorborne infections in cats: molecular study in Barcelona area (Spain). Vet Parasitol 2008; 151(2-4): 332-336. PMid:18079064. http://dx.doi. org/10.1016/j.vetpar.2007.10.019

Tarello W. Microscopic and clinical evidence for Anaplasma (Ehrlichia) phagocytophilum infection in Italian cats. Vet Rec 2005; 156(24): 772-774.

Thompson JD, Higgins DG, Gibson TJ. CLUSTAL W: improving the sensitivity of progressive multiple sequence alignment through sequence weighting, position-specific gap penalties and weight matrix choice. Nucleic Acids Res 1994; 22(22): 4673-4680. PMid:7984417. PMCid:308517. http://dx.doi.org/10.1093/nar/22.22.4673

Walker DH, Dumler JS. Emergence of the ehrlichioses as human health problems. Emerg Infect Dis 1996; 2(1): 18-29. PMid:8903194. PMCid:2639805. http://dx.doi.org/10.3201/eid0201.960102

Yin-Chiachun, Liu-Hungjen, Lin-Suenchuain, Liao-Minghuei, Wu-Yeonghuey. Identification of Ehrlichia canis in cats by nested polimerase chain reaction and nucleotide sequence analysis. Taiwan Vet J 2003; 29(2): 122-128. 